DOI 10.15826/qr.2016.4.197

УДК 821.161.1-145Тютчев+821.111-145Блейк

\title{
WAVES OF INFINITY IN THE GOBLET OF THE IMAGINATION*
}

\author{
Oleg Donskikh \\ Novosibirsk State University \\ of Economics and Management, \\ Novosibirsk, Russia
}

...Body also is infinite, and that there is an infinite number of worlds. Why should there be body in one part of the void rather than in another? Grant only that mass is anywhere and it follows that it must be everywhere. Also, if void and place are infinite, there must be infinite body too, for in the case of eternal things what may be must be.

Aristotle. Physics

In this article, the poetic worlds of Fyodor Tyutchev and William Blake are analysed in terms of their comprehension of infinity. Both of them combine their notion of infinity with an understanding that the divine is manifested in the tangible world. The article demonstrates that Tyutchev talks about two infinities the daily one, which establishes the divine unity of existence, and the nightly one, which leads everything into chaos. They can be easily recognised as the actual and potential infinities in the philosophy of Aristotle. Blake recognises infinity as the procedural deployment of the Universe and, at the same time, as the divine foundation of everything: this allows all things to be part of unified universal space. For him, the infinite and eternal essence of each thing (taking into account that everything is infinite and eternal at every point in space and time) fills things with their inner light and allows them to witness God. The opportunity to perceive nature like this is given by the loving heart and a vivid imagination, but is closed to both human and universal reason. The infinity perceived by reason is just a dark void, which closes worlds and separates them from each other.

Keywords: F. Tyutchev, W. Blake, actual infinity, potential infinity, eternity.

* Citation: Donskikh, O. (2016). Waves of Infinity in the Goblet of the Imagination. In Quaestio Rossica, vol. 4, № 4, p. 148-161. DOI 10.15826/qr.2016.4.197.

Цитирование: Donskikh O. Waves of Infinity in the Goblet of the Imagination // Quaestio Rossica. Vol. 4. 2016. № 4. P. 148-161. DOI 10.15826/qr.2016.4.197.

(C) Donskikh O., 2016

Quaestio Rossica • Vol. 4 • 2016 • № 4, p. 148-161 
Анализируются поэтические миры Федора Тютчева и Уильяма Блейка с точки зрения их понимания бесконечности. Оба поэта связывают свое понятие бесконечности с тем, как Божественное проявляется в материальном мире. Показано, что Ф. Тютчев говорит о двух бесконечностях - дневной, которая манифестирует Божественное единство бытия, и ночной, которая ведет все к хаосу. Они вполне соответствуют понятиям актуальной и потенциальной бесконечности в философии Аристотеля. У. Блейк понимает бесконечность как процессуальное развертывание Вселенной и в то же время как Божественную основу всего. Это позволяет всем вещам быть частью единого вселенского пространства. Для него бесконечная и вечная сущность каждой вещи (учитывая, что все оказывается бесконечным и вечным в каждой точке пространства и времени) заполняет все своим внутренним светом и позволяет им свидетельствовать о Боге. Это дает возможность воспринимать природу так, как это дано любящему сердцу и живому воображению, но такое восприятие закрыто для разума, будь он человеческий или вселенский. Бесконечность воспринимается разумом лишь как темная пустота, которая закрывает миры и отделяет их друг от друга.

Ключевые слова: русская литература XIX в.; английская литература XIX в.; Ф. Тютчев; У. Блейк; бесконечность; вечность.

Infinity is not and cannot be perceived by the senses: it is revealed by reason. This is because the senses by definition can perceive only what is finite and limited. Reason overcomes this limitation as soon as it takes the limited as limited, thus opposing it to infinity. Reason goes beyond anything finite by contrasting it to the infinite as relative to the absolute. As soon as reason places this border it appears, even if prior to this there was no border. Yet it appears along with a puzzle about what is beyond the border. Is there anything? Is there any other border? What is beyond that? Or are there no borders - just boundlessness? The absence of borders (chasm, abyss, darkness) cannot be perceived, but can be experienced and recorded correspondingly. It can be experienced as the fact of absence. For instance, a man knows that there is small backyard behind the house. He bypasses the house and discovers that there is no backyard. This absence becomes a specific feeling. For reason, however, infinity is a problem. It can be reflected upon in different ways, it can be taken for granted or negated, but nonetheless it immediately exists as a fact of consciousness. The infinite is uncovered by philosophy and mathematics. It can also be found through poetry. The difference from philosophical or mathematical reasoning is that poetry uncovers infinity as a particular experience and not as a logical structure. In order to comprehend the way poets deal with the conceptimage of infinity, we will turn to the metaphysical poetry of Tyutchev and Blake. They have been chosen due to the deep feeling for a reality beyond the visible one expressed in their works. 


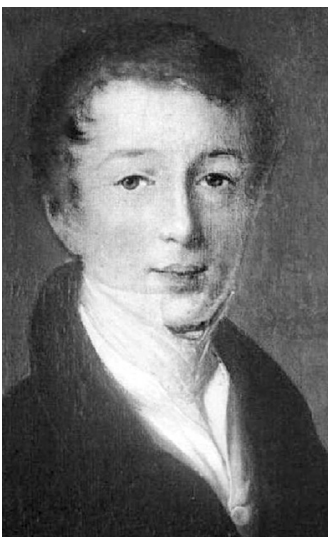

The young Tyutchev. Notable painter. Moscow.

The end of 1810

Let us have a look at Tyutchev first. In the poem "Spring" (1837), he wrote1:

Игра и жертва жизни частной!

Приди ж, отвергни чувств обман

И ринься, бодрый, самовластный,

В сей животворный океан!

Приди, струей его эфирной

Омой страдальческую грудь -

И жизни божеско-всемирной

Хотя на миг причастен будь! (т. 1, с. 97)².

Our feelings are limiting, confining us to our private living space; therefore, in order to touch life in its entirety and infinity, it is necessary to realise oneself as a part of divine, universal life. This life, like St Augustine's God, is always in present time. It confronts time, being absolutely full and clean. When time appears, the past appears as well, and chaos is born". The poem "Columbus" (written seven years later) stipulates that it is reason, and not sensations, that link us with the divine essence of nature:

\author{
Так связан, съединен от века \\ Союзом кровного родства \\ Разумный гений человека \\ С творящей силой естества... (т. 1, с.102) ${ }^{4}$.
}

Four years later, the poem "Sea and Cliff" opposes the steady, eternal, and insensible cliff to the evil waves in the same manner:

${ }^{1}$ Tyutchev's poems are quoted from: [Тютчев].The poems are presented in interlinear translation. If only the page number is indicated, this means the cited verse is in the first volume.

${ }^{2}$ The game and victim of private life!

Come here, rejecting the lie of feelings

And plunge, being vigorous and self-possessive,

Into this life-giving ocean!

Come, and wash your suffering breast

With its aether spray -

And share the divine-worldwide life

For at least a moment!

${ }^{3}$ In Tyutchev's weltanschauung, chaos is an inaccessible part of the past which can be only felt in the silence of the night (see: [Донских]). It is worthwhile noting that the ether in this poem reminds us of Aristotle's doctrine of the unchangeable heavens, which consist of imperishable ether beyond the changeable sublunary sphere of the four elements. However, it is very possible that Tyutchev did not intend this association.

${ }^{4}$ This way it is linked, united

By the union of consanguinity

The rational genius of man

With the creating force of nature. 


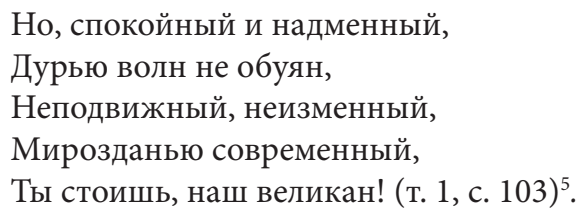

Thus infinity characterises the essence of the natural and the genuine. It is closely associated with the genuine, and only exists in connection with it.

Along with this understanding, there is another series of associations with infinity. See, for instance, the poem "The Dawn", which was written at about the same time as "Sea and Cliff":

Ночь бесконечная прошла,

И скоро светлый день настанет... (т. 2, с. 109)

In this case, infinity is revealed as the feeling of something which is not seen during the day because the day envelops us with cover and thus separates us from the abyss. The night rips off this cover from the fateful world (fateful-роковой / rokovoi-means here that the world is temporary, it has a beginning and an end). The night reveals to man "the unnamed abyss" with its "fears and mists" [compare with Frank].

The word "unnamed" is conspicuous in this context because it emphasises the irrationality of this feeling. After all, the abyss is beyond any possibility of denotation as the corresponding sense cannot be related to anything; at the same time, it cannot possibly be perceived via sensation. That is why the description of this abyss is so contradictory: on the one hand, it is filled with mist (which is not something by itself since it only covers something else), and, on the other, fears (i. e. not something that can be sensed, but the feeling itself) characterise man's state and do not relate to the abyss. The expression "the infinite night has gone" is also contradictory, Logically it is impossible, since such an expression cannot be verified: common sense would reject it straight away. It is not significant in this case whether time or space is considered. In other words, infinity is felt as a set of conscious contradictions. Infinity is felt as something onerously impossible, which stops in the particular moment. In contrast to the night, the day is finite: it is limited in time and space, it is definitely opened to feelings. This means that infinity is revealed dually: during the day as the absolute integrity of divine life and during the night as the bottomless abyss. These are "daily" and "nightly" infinities. These can be seen as two different aspects of the same infinity or as two different infinities.

\footnotetext{
${ }^{5}$ However, serene and arrogant,

Not overwhelmed by the foolishness of waves

Motionless, unchangeable

As old as the universe

You are standing, our giant.

${ }^{6}$ The infinite night has gone,

And the light day will come soon...
} 
Let us consider what associations emerge in relation to the word неизмеримость (literally "immeasurability"). One infinity reveals itself when day is replaced by night. This occurs in the poem "The East Is Remaining Silent" (1865):

Еще минута, и во всей

Неизмеримости эфирной

Раздастся благовест всемирный

Победных солнечных лучей... (т. 1, с. 202)7 .

The second infinity emerges when night replaces day, as in the poem "As the Ocean Embraces the Terrestrial Globe" (1830):

То глас ее: он нудит нас и просит...

Уж в пристани волшебный ожил челн;

Прилив растет и быстро нас уносит

В неизмеримость темных волн (т. 1, с. 29)8.

In the first poem, Tyutchev speaks about the infinity of the world as the wholesome light of sunrays. This is the infinity of "the divine-universal life". In the second, he discusses infinity going into the darkness, into obscurity. It looks as if we can distinguish between daily and nightly infinities. Without straining our interpretation, we can also denote them as actual and potential infinities, which were described by Aristotle. If there is an infinite amount of things in some limited volume, we have actual infinity; if the continuation of something is possible at any time without any limitation (like the continuation of a straight line in both directions), we have potential infinity. However, there is a difference between these definitions and Tyutchev's ideas. The infinities are given to him by his perceptions, but are also simultaneously rational and sensational. Actual infinity exists for the poet out of time, while, in contrast, potential infinity exists for him in time. These perceptions are quite consistently presented by Tyutchev in different contexts with words such as беспредельное (unlimited) and бездна (abyss).

In the famous poem "What you are whining about, night wind?" (1830), we can see:

Как жадно мир души ночной

Внимает повести любимой!

\footnotetext{
${ }^{7}$ One more minute, and in all

Aetheric immeasurability

The toll will start

Of the victorious sunrays.

${ }^{8}$ This is its [the element's] voice, it is forcing and asking us...

The magic boat comes to life in the wharf

The tide is growing and quickly carries us out

Into the immeasurability of the black waves.
} 
Из смертной рвется он груди,

Он с беспредельным жаждет слиться!..

О! бурь заснувших не буди -

Под ними хаос шевелится!.. (т. 1, с. 57) 9

The poet is presenting here nightly (potential) infinity, which cannot be embraced or even realised. We touch it and we merge with it, but we are not able to embrace it completely with either sensation or reason. Consequently, it is frightening to us. The more we try to ponder upon it, the more we slip out of our world.

In contrast, in the poem "The coffin is already lowered down into the grave" (1835), actual infinity is presented as the perception of infinite wholeness, as the unlimited abyss of the sky:

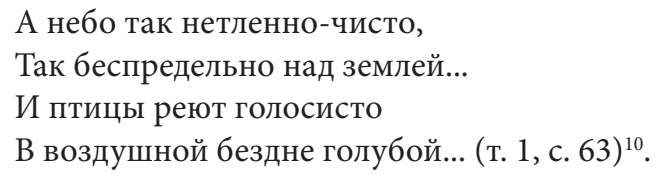

The interpretation of this word may be rather strained, but yet it is quite obvious that in these two fragments the same difference in relation to the unlimited can be easily observed as in the fragments that relate to immeasurability.

In the aforementioned poem "Columbus", the world (actual infinity) is brought to light by hazy boundlessness (potential infinity):

\section{И новый мир, неведомый, нежданный, Из беспредельности туманной$$
\text { На Божий свет ты вынес за собой (т. 1, с. 102) }{ }^{11} \text {. }
$$

Exactly the same difference between daily (actual) and nightly (potential) infinities can be found in Tyutchev's use of the word бездна (abyss).

In the poem above, actual infinity is the "the airy blue abyss". In "The Swan" (1838-1839), three actual infinities are manifested: two abysses (watery and airy elements) and the glory of the starry firmament.

\footnotetext{
${ }^{9}$ How greedily the world of the nightly soul

Is listening the favorite story!

It is rushing from the breast,

It is trying to join the unlimited!

Oh, do not wake up the sleeping tempests -

Chaos is wiggling below them.

${ }^{10}$ Yet sky is so imperishably clean,

So unlimited beyond the earth...

And the birds are flying vociferously

In the airy blue abyss...

${ }^{11}$ And the new world, unknown, unexpected

From the hazy boundlessness

You brought to divine light with yourself.
} 
Она, между двойною бездной,

Лелеет твой всезрящий сон -

И полной славой тверди звездной

Ты отовсюду окружен (т. 1, с. 26) ${ }^{12}$.

It is worth noting that Blaise Pascal in his Pensées (Thoughts) also talks about the position of human beings on the crossroads between three infinities, though he presents them differently as infinity in space, time, and on the scale from the infinitely small to the infinitely large. Given that Tyutchev knew Pensées (as can be shown through his use of the image of "the thinking reed" in the poem "There is melodiousness in the sea waves..." (1865)), such an influence is probable.

In contrast to daily infinity, nightly infinity absorbs everything it touches. This idea is clearly expressed by Tyutchev in the poem "From the life which was raging here" (1871). He presents nature as the manifestation of potential infinity:

Поочередно всех своих детей,

Свершающих свой подвиг бесполезный,

Она равно приветствует своей

Всепоглощающей и миротворной бездной (т. 1, с. 225) ${ }^{13}$.

Everything is disappearing into infinity, losing its individuality. This is happening in time. Nightly infinity is presented in the poem "K. N."(1824) in the following way:

Таков горе духов блаженных свет,

Лишь в небесах сияет он, небесный;

В ночи греха, на дне ужасной бездны,

Сей чистый огнь, как пламень адский, жжет (т. 1, с. 11) ${ }^{14}$.

This loss of individuality is ambivalent for the poet: it is tempting and scary at the same time. Take, for example, the poem "Look at the River's Expanse" (1851):

\footnotetext{
${ }^{12}$ It [element] in between double abyss

Is cherishing your all-seeing dream -

And you are surrounded from everywhere

By the whole glory of the starry firmament.

${ }_{13}$ Alternately all its children

Committing their useless labour

It [nature] equally greets by its

All-absorbing and concordant abyss.

${ }^{14}$ Such is up there the light of the blessed spirits,

It is shining only in the heavens, being supernal,

In the night of sin, on the bottom of the terrible abyss

This pure fire is burning as the infernal blaze.
} 


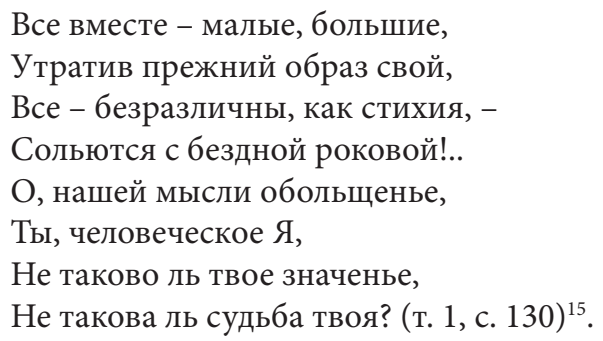

This loss of individuality is experienced as temptation and fear simultaneously, which is emphasised by the word "fatal": this links us with nightly potential infinity, given to us in our everyday life.

Thus Tyutchev discusses the existence of two kinds of infinity - daily (actual) and nightly (potential), which are given to us via our perceptions ${ }^{16}$. They are differentiated on the basis of their distinct links to the external world. While actual infinity unites us with the divine and originally timeless essence of the world, potential infinity takes us in time out of world, along with everything which exists in time, to the abyss of chaos ${ }^{17}$ : the stirring of the night reminds us about the frailty of existence.

Let us now turn to William Blake. Tyutchev, in accordance with his aphoristic style, mentions infinity quite infrequently. In contrast, Blake, being very verbose, piles images one on top of the other and constantly appeals to infinity. ${ }^{18}$ References to infinity in his work can be easily found in different contexts. For instance, in the poem "The Marriage of Heaven and Hell", we find "By degrees we beheld the infinite Abyss, fiery..."or "On those infinite mountains of light... the newborn fire stood ..." (p. 188).$^{19}$ Here infinity is taken in a simple, procedural sense: it is something which is gradually opened to the senses. However, in accordance with the concept of infinity, it cannot be opened up to the end. It is possible to talk about simple hyperbolic exaggeration: the very big is presented as enormously big (see: [Holmes]).

${ }^{15}$ They [the ice floes] altogether - small and large,

Losing their previous images

Everything, indifferent as the element,

Will merge the fatal abyss.

Oh, being the temptation of our thought,

You, the human I,

Is not this your meaning,

Is not this your destiny?

${ }^{16}$ These kinds of infinity correlates to the crucial difference between "up" and "down" in Tyutchev's worldview. See: [Лотман].

${ }^{17}$ Chaos in Tyutchev's poetics is the forgotten feelings and memories which cannot be reached any more even in dreams (see: [Донских]), and this explains the Sarah Pratt's statement that "the image of chaos that unites the poems of Tjutčev's chaos cycle is a conglomerate phenomenon comprised of various related aspects" [Pratt, p. 102].

${ }^{18} \mathrm{I}$ wish to make it clear that I am not touching on Blake's mythology in this article: rather, I am exclusively discussing the expression of temporary and spatial parameters in his poems. At the same time it is obvious that, once we have taken Blake's wordiness and ambiguity into account, it is difficult to consider all the different contexts; as such, the conclusions may look too straightforward. However, it is important for me to convincingly demonstrate the eligibility of the resulting statements.

${ }^{19}$ All quotes are from: [Poetry and Prose of William Blake]. 
The next step is the image of infinity as a constituent of every particular thing. In these cases, infinity is the overcoming of the finiteness and boundedness of human perception. In two sets of arguments related to natural religion, Blake opposes sense to reason on the grounds that infinity cannot be perceived by senses, only by reason. Yet, at the same time, "Man by his reasoning power can

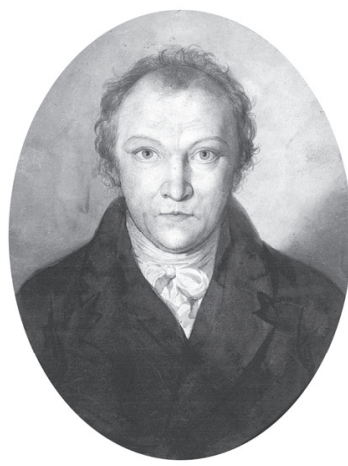

William Blake. Self-portrait. 1802. Pencil, paper. Collection of Robert N. Essick only compare \& judge of what he has already perceiv'd" (p. 147). Nonetheless, in contradiction to this statement, Blake argues that, in reality, man perceives more than the sense organs allow. A man is a human being because he is trying to perceive more and more. “...Less than All cannot satisfy Man." Blake continues: "He Who sees the Infinite in all things, sees God. He Who sees the Ratio only, sees himself only" (p. 148). Reason is limiting and, therefore, reduces everything. This is an act of Satan in contrast to an act of God. In other words, reason covers man and fences off the rest of the world, leaving him alone. Blake expresses this understanding of the act of reason quite consistently.

The poet insists that infinity can be humanly perceived by the one who is eager to perceive: infinity irrefutably proves the presence of the divine in nature. However, when he discusses human senses, he is also talking about supersensible perception. In this case, he is referencing direct perception of the divine, which Vladimir Soloviov called 'the mystical. This is much closer to intuition than to perception as such. In the aforementioned "Marriage of the Heaven and Hell", the poet is having dinner with the prophets Isaiah and Ezekiel and asks them why they are so confident that they were communicating with God. Isaiah answers: "I saw no God, nor heard any, in a finite organical perception; but my senses discover'd the infinite in everything..." (p. 185-186). Ezekiel also says that his aim was "...The desire of raising other men into a perception of the infinite..." (p. 186). This can be reached by perfecting sensual perception: "If the doors of perception were cleansed every thing would appear to man as it is, infinite." (p. 187). Blake is talking here about two worlds - the one which we are inhabiting in the here and now and the ideal one, where everything is infinite and eternal. What is the meaning of this infinity for Blake? It is possible that he identifies infinity with eternity - it is a sort of unity. The finite given thing is always part of the infinite and unchangeable (which means eternal) divine world.

The overcoming of this limitedness and the revealing of infinity is the principal aim of the poet. It is not accidental that this noble aspiration is manifested in these famous lines from "The Auguries of Innocence": 
To see a World in the Grain of Sand

And a Heaven in a Wild Flower,

Hold Infinity in the palm of your hand

And Eternity in an hour (p. 118).

Thus Blake is actually talking about religion in the sense which European culture inherited from Late Antiquity: the term 'religion' derives from 'religio', meaning a reunion of God and Man, the bridge between the limited and the infinite.

However Blake does not bind himself by stating that the infinite world contains limited things which are accessible to simple perception. $\mathrm{He}$ is literally stating that every thing has its own infinite and eternal analogue. In fact, he is referring to the Platonic world of eidoses, prototypes. Yet, for Blake, each of them is also infinite: this would certainly terrify Plato, because for him the absolute specificity of any eidos is the foundation of his doctrine of the ideal world.Letus consider a line in the poem "America": "And Earth had lost another portion of the infinite..." (p. 207). In context, this means that if America lost the war to England, if it was not born as a new phenomenon, one of the earthly infinities would be lost. This in turns means that a limited phenomenon, America in this case, bears a part of the earthly infinite inside itself. The scale is thus changed - the limited is transformed into the infinite and vice versa. Kierkegaard in Fear and Trembling comes close to this understanding when he insists that the power of faith is manifested in the transformation of the singular into the infinite. The same can be seen in the poem "Europe" "...Silent the Angel [of Albion] went Along the infinite shores of Thames..." (p. 215). Here Albion, in its ideal state, is taken as the image of eternal England. In the same context, the following line can be read: "Every thing in Eternity shines by its own Internal light...” (p. 386). Satan (Reason) is trying, sometimes successfully, to extinguish this inner fire. He transforms the existing world into dreams or abstractions, which sterilely populate "the infinite ages of eternity". ${ }^{20}$ As far as I can understand Blake, he thinks that Reason, being aware of the infinity existing in the world, is doing everything it can to isolate human beings from the world and existence as a whole: it thus separates humanity from divine infinity. There is another condition which prevents consciousness of infinity from uniting everything. Infinity integrates everything together if there is love. If there is no love, infinity is ruinous. It turns into the hiatus, the void which leads nowhere. The void does not exist because it is nothing. Filled with jealousy, Albion is perishing, as are all of its parts. We read in the following lines of the poem "Jerusalem" that:

${ }^{20}$ In Blake's mythology, Reason is personified as Urizen. Sometimes Satan is identified as Urizen. Take, for example, the following line from "The book of Ahania": "For in Urizen's slumbers of abstractionIn the infinite ages of Eternity (p. 238). 
The banks of the Thames are clouded! the ancient porches of Albion are Darken'd! they are drawn thro' unbounded space, scatter'd upon The Void in incoherent despair! Cambridge \& Oxford \& London Are driven among the starry Wheels, rent away and dissipated In Chasms \& Abysses of sorrow, enlarg'd without dimension, terrible

There is perishing, but there is no void. New and new worlds are born in the void.

Satan tempts humanity, imposing upon him reasonable, understandable, and limited images. Thought is trying to avoid the uncertainty which is brought about by infinity. Infinity is discovered by meekness and love. ${ }^{21}$ They destroy the human I: only God fills human life. In order to come to God, one has to reject one's own I. The human fears to do this, which is quite strange because this is the only way to find his or herself. This is different from Tyutchev with his ambivalent attitude to the loss of the I. Blake, in contrast, is directly sending the human being towards self-destruction so that he or she can acquire genuine life.

The thought which is afraid of infinity changes "the infinite to a serpent... and man fled from its face and hid In forests of night..." (p. 216). It should be said that while this line in the poem "Europe' is not immediately clear, it quite comprehensibly conveys the idea that infinity overcomes everything except the limitations of the body: here, reason and passions rule. Humans are prepared to create their own world where God is a tyrant just in order not to lose the I. However, this path leads to death. Only rejection of the I leads to life: "To bathe in the Waters of Life; to wash off the Not Human I come in Self-annihilation \& the grandeur of Inspiration To cast off Rational Demonstration by Faith in the Saviour To cast off the rotten rags of Memory by Inspiration To cast off Bacon, Locke \& Newton from Albions covering" (p. 430). It is not coincidental that empiricist philosophers and Sir Isaac Newton are mentioned in this context. In the first book of the poem "Milton", Blake directly expresses his understanding of infinity:

The nature of infinity is this: That every thing has its

Own Vortex; and when once a traveller thro' Eternity

Has pass'd that Vortex, he percieves it roll backward behind

His path, into a globe itself infolding; like a sun,

Or like a moon, or like a universe of starry majesty,

While he keeps onwards in his wondrous journey on the earth

Or like a human form, a friend with whom he liv'd benevolent

(p. 392).

${ }^{21}$ See: “O Saviour pour upon me thy spirit of meekness \& love!" (p. 436). 
'This image can be interpreted as a poetical form of the Cartesian doctrine of world vortices. Newton criticised Descartes for this doctrine in his "Mathematical Principles of Natural Philosophy" and wrote that if the hypothesis of vortices (which were constantly formed by the rotation of the celestial bodies) was accepted, the solar system would lose its stability. Blake was rather hostile to Newton, and therefore he was inclined to accept the Cartesian doctrine. Newton wrote about God and the Universe that: It is the dominion of a spiritual being which constitutes a God: a true, supreme, or imaginary dominion makes a true, supreme, or imaginary God. And from his true dominion it follows that the true God is a living, intelligent, and powerful Being; and, from his other perfections, that he is supreme, or most perfect. He is eternal and infinite, omnipotent and omniscient; that is, his duration reaches from eternity to eternity; his presence from infinity to infinity; he governs all things, and knows all things that are or can be done' [Newton].

In this perfect and reasonable universe, it is not possible for vortices to determine the basic movement of celestial bodies. Newton demonstrates that the hypothesis of vortices encounters too many difficulties, and therefore their existence would violate the perfection of the Universe. ${ }^{22}$ This perfect world is repulsive for Blake because 1) it is absolutely rational and therefore excludes the senses and 2) it assumes the existence of a void. As was already mentioned, Blake could not tolerate the very idea of a void. Newton's physics accepted a void through which celestial bodies could influence each other via gravity. This is a purely mechanical structure which directly excludes wonder and the irrationality of the senses. In contrast, Cartesian physics assumes that all bodies are linked with each other through the movement of vortices, which is unpredictable.

In "Milton", Blake writes that the spectre of Luvah (the symbol of Eros, the enemy of Reason) is living "In the Newtonian Voids between the Substances of Creation For the Chaotic Voids outside of the Stars are measured by The Stars, which are the boundaries of Kingdoms, Provinces And Empires of Chaos invisible to the Vegetable Man" (p. 425). In other words, there are no voids: these are just invisible worlds ${ }^{23}$. That is why the empiricists, who only accept tangible things, should not be trusted.

The world of reason, supported by experience, is just empty infinity, which means death. Reason itself is playing the role of death: "Eternity groan'd\& was troubled at the Image of Eternal Death. The Wandering Man bow'd his faint head and Urizen descended - And the one must have murder'd the Man if he had not descended - Indignant, muttering low thunders, Urizen descended, Gloomy sounding: "Now I am God from Eternity to Eternity" (p. 260). Reason itself is closed, and it tears everything apart, relating objects exclusively to itself and depriving them of links with any-

${ }^{22}$ This is emphasized by Alexandre Koyré: (Койре А. Очерки истории философской мысли. М. : Прогресс, 1985. С. 234).

${ }^{23}$ The complexities of Blake's images and concepts in "Milton" are discussed by Fry and Howard, yet their observations are in some aspects different from what is presented here [Fry; Howard]. 
thing else, because these links can be arranged only through divine infinity. Breaking the links means that reason is generating the void. In its turn, the void is generating horror. This horror is intangible, hidden in the darkness, because closed things are deprived of inner light. In The First Book Of Urizen Blake writes: “... a shadow of horror is risen In Eternity! Unknown, unprolific, Self-clos'd, all-repelling: what Demon Hath form'd this abominable void, This soul-shudd'ring vacuum? Some said "It is Urizen." But unknown, abstracted, Brooding, secret, the dark power hid" (p. 220). Reason generates infernal infinity: "Times on times he divided \&measur'd Space by space in his ninefold darkness, Unseen, unknown...” (Ibid.).

Thus, the divine infinity of the world is opposed to the "fathomless void" where one can fall endlessly. This way Los (personification of the Sun, the eternal prophet) is falling into the darkness where there is no day or night, where space is measured only by infinite rotation of the terrible "fathomless void" (p. 244). ${ }^{24}$

Finally, let us discuss one more remarkable motif. Blake consistently presents the idea of everything in everything, all in all. This is the idea of the flexibility of space and time - that is, in the infinity an infinite amount of worlds are born and each moment of time can turn into millennia. "Then Eno, a daughter of Beulah, took a Moment of Time And drew it out to seven thousand years with much care \& affliction And many tears, \& in every year made windows into Eden. She also took an atom of space \&open'd its centre Into Infinitude \&ornamented it with wondrous art" (p. 257). ${ }^{25}$

We can conclude, that both Tyutchev and Blake link infinity with the comprehension of divinity. Tyutchev is talking about two infinities - the daily one, which establishes the divine unity of existence, and the nightly one, which leads everything to chaos. They can be understood as the actual and potential infinities of philosophy and mathematics. For Blake, infinity is the procedural deployment of the universe; more significantly, it is the divine foundation of everything, and thus makes everything part of an integral world space. Explicitly, the infinite and eternal essence of each thing (taking into account that everything is infinite and eternal in every point of space and time) creates an inner light and allows us to witness God. This is revealed in the loving heart and imagination, and is closed to reason. The infinity of reason is a dark void. It closes worlds and separates them from each other.

\section{Список литературы}

Донских О. А. Вслушиваясь в гулкую тьму ушедшего (Тютчев о хаосе) // Сибир. филол. журн. 2003. № 3-4. С. 67-75.

Лотман Ю. М. Заметки по поэтике Тютчева // Лотман Ю. М. О поэтах и поэзии. СПб. : Искусство, 1996. С. 553-564.

Тютчев Ф. И. Лирика : в 2 т. М. : Наука, 1995. Т. 1. 448 с. Т. 2.512 с.

${ }^{24}$ Compare: The Book of Los. “...Day \& night without end; For tho' day or night was not, their spaces Were measur'd by his incessant whirls In the horrid vacuity bottomless" (p. 244).

${ }^{25}$ Beulah is the analogue of the heavens in Blake's mythology. 
Франк С. Л. Космическое чувство в поэзии Тютчева // Русская мысль. 1913. Кн. 11. Damrosh L. Symbol and Truth in Blake's Myth. Princeton : Princeton Univ. Press, 1980. 395 p.

Fry N. Notes for a Commentary on Milton // The Divine Vision : Studies in the Poetry and Art of William Blake. L. : Gollancz, 1957. P. 99-137.

Holmes R. The Greatness of William Blake // The N. Y. Rev. of Books. 2015. Dec. 3. Vol. 62, No. 19.

Howard J. Blake's Milton : A Study in the Selfhood. N. Jersey ; L. : Fairleigh Dickinson Univ. Press, 1976. 300 p.

Newton I. The Mathematical Principles of Natural Philosophy (1846). URL: https://en.wikisource.org/wiki/The_Mathematical_Principles_of_Natural_Philosophy_ (mode of access: 28.11.2015).

Poetry and Prose of William Blake : Complete in one volume / ed. by G. Keynes. L. : The Nonesuch Press ; N. Y. : Random House, 1948. 936 p.

Pratt $S$. The Semantics of Chaos in Tjutčev. München : Verlag Otto Sagner, 1983. 149 p. Slavistische Beiträge. Band 171.

\section{References}

Damrosh, L. (1980). Symbol and Truth in Blake's Myth. 395 p. Princeton, Princeton Univ. Press.

Donskikh, O. A. (2003). Vslushivayas'v gulkuyu t'mu ushedshego (Tyutchev o khaose) [Listening the Reverberant Darkness of the Past (Tyutchev on Chaos)]. In Sibirsky filologichesky zhurnal, 3-4, pp. 67-75.

Frank, S. L. (1913). Kosmicheskoe chuvstvo v poezii Tyutcheva [The Feeling of Cosmos in Tyutchev's Poetry]. In Russkaya mysl'. Book 11.

Fry, N. (1957). Notes for a Commentary on Milton. In The Divine Vision : Studies in the Poetry and Art of William Blake (pp. 99-137). L., Gollancz.

Holmes, R. (2015). The Greatness of William Blake. In The N. Y. Rev. of Books, Dec. 3, Vol. 62, No. 19.

Howard, J. (1976). Blake's Milton. A Study in the Selfhood. 300 p. N. Jersey, L., Fairleigh Dickinson Univ. Press.

Keynes, G. (Ed.). (1948). Poetry and Prose of William Blake: Complete in one volume. 936 p. L., The Nonesuch Press, N. Y., Random House.

Lotman, Yu. M. (1996). Zametki po poetike Tyutcheva [Notes on Tyutchev's Poetics]. In Lotman, Yu. M. O poetakh i poezii (pp. 553-564). Saint Petersburg, Iskusstvo.

Newton, I. (1846). The Mathematical Principles of Natural Philosophy. URL: https://en.wikisource.org/wiki/The_Mathemātical_Principles_of_Natural_Philosophy_ (mode of access: 28.11.2015).

Pratt, S. (1983). The Semantics of Chaos in Tjutčev. Slavistische Beiträge. Band 171. 149 p. München, Verlag Otto Sagner. Nauka.

Tyutchev, F. I. (1995). Lirika : v 2 t. [Poems]. Vol. 1. 448 p. Vol. 2. 512 p. Moscow, 